\title{
Institutional Micro Credit Determinants and Portfolio Quality of Investment Groups
}

\author{
Dr. Fredrick M.Kalui, \\ Department of Accounting, Finance and Management Science, \\ Egerton University, Njoro, Kenya
}

Doi:10.19044/esj.2020.v16n4p191～URL:http://dx.doi.org/10.19044/esj.2020.v16n4p191

\begin{abstract}
Micro-credit plays a major role in development strategies. This is in view of its direct relationship to both poverty alleviation and improvement of the living standards. However, commercial banks are still largely absent in the provision of micro credit. This phenomenon may be attributed to credit policies associated with loans provided by the formal sector. Since many businesses in small and micro enterprise sector are largely poor and lack tangible assets that can be pledged as collateral in conventional lending, banks are unwilling to provide credit facilities to them. For this reason, The objectives of the study were to determine the effects of macroeconomic, group leverage, group capitalization and group characteristics on the portfolio quality of investment groups financed by the Sidian bank in Nairobi region The study adopted a descriptive survey research design since it establishes the relationship between the dependent and the independent variable. With the target population being all the 56 investment groups in the 9 branches under the Sidian bank within Nairobi region. The study used secondary data, which was obtained from the Sidian bank offices in each of the branches within Nairobi region. Data analysis was conducted using descriptive statistics including percentages, frequencies, means and standard deviation. In addition, inferential analysis was carried out using correlation analysis and multiple regression analysis. The study found that macroeconomic variables, group leverage level, group capitalization and group characteristics influences portfolio quality of investment groups financed by the Sidian bank in Kenya positively and significantly. The study concluded that group leverage level had the greatest influence on portfolio quality of investment groups financed by Sidian bank in Kenya followed by macroeconomic variables, group capitalization level and finally group characteristics had the least effect. The study recommends that the Sidian bank need to manage their portfolios, by understanding that not only the risk posed by each credit but also how the risks of individual loans and portfolios are interrelated. The study also
\end{abstract}


recommended that, banks should be allowed to invest more in loans and advances as long as such banks have enough reserves to finance such investments. The study further recommends that regulatory authority (CBK) and other stake holders should create an enabling environment that removes all these inefficiencies to the policy concern of high cost of credit.

Keywords: Micro Credit Determinants, Portfolio Quality, Investment Groups

\section{Introduction}

Commercial banks have for long been the main lenders in all economies worldwide. This has made access to formal credit by small-scale businesses and particularly among the low-income earners quite difficult. Research has shown that micro credit plays a major role in development strategies. This is in view of its direct relationship to both poverty alleviation and improvement of the living standards. Both World Bank (2014) and United Nations Development Programme (UNDP) (2011) confirm that access to credit and gender inequalities in developing societies inhibit economic growth and development. Further, societies that discriminate based on gender have lower credit accessibility, greater poverty, slower economic growth, weaker governance, and a lower standard of living.

Micro-credit plays a major role in development strategies. This is in view of its direct relationship to both poverty alleviation and improvement of the living standards. However, commercial banks are still largely absent in the provision of micro credit. This phenomenon may be attributed to credit policies associated with loans provided by the formal sector (Milani, 2014). Since many businesses in the small and micro enterprise sector are largely poor and lack tangible assets that can be pledged as collateral in conventional lending, banks are unwilling to provide credit facilities to them. In addition, the presence of moral hazard in many developing countries means that credit rarely reaches desired clients and, in many cases, there is no obligation to repay the loans. Moreover, the costs associated with administering and monitoring credit services are quite high. To bridge this gap, the micro finance institutions have developed specific policies that target and feed loans to the small-scale enterprises. Research show that the providers of micro credit, who are mainly micro finance institutions, are faced with the challenge of high default rate on loans advanced, sound credit management techniques are rarely in place, and even if they are, they are largely ignored.

To assist in start-up businesses or to grow an existing venture, the Sidian bank credit facility is provided through a group or on individual basis (Mwangi \& Muturi, 2016). Group loans are based on traditional rotation credit arrangement, which has received large amounts of attention in recent years from the major development agencies and banks. Micro-credit takes care of 
the under privileged in the society who have no likelihood of accessing financial services from the commercial banking sector. The ultimate goal of micro-finances is to help low-income earners become self-reliant and sufficient through provision of micro-saving, borrowing and insurance cover (Milani, 2014).

Credit is granted on faith and the ability of a borrower to make future payments (Liu and Zhu, 2010). According to Basel Committee 2006 Chorafas (2009), a default is considered to have occurred with regard to a particular obligor when either or both of the two following events take place. The bank considers that the obligor is unlikely to pay its credit obligations to the banking group in full, without recourse by the bank to actions such as realizing security and the obligor is past due more than 90 days on any material obligation to the banking group. That is a loan is in default occurs when a borrower fails to meet a principal or interest payment of a loan, unless arrangements are made to pay at a later date than previously agreed upon. The undesirable trend of increasing rates of default proves costly to all parties concerned in the process of borrowing and lending. Non-payment equally affects the lender and the borrower negatively (Poghosyan, 2013). On the one hand, the lender loses the part of the principal loan disbursed and earnings in the form of interest. On the other hand, the borrower faces a bleak future in obtaining credit due to lower credit rating.

\section{Statement of the problem}

Many small enterprises and low-income earners always find it difficult to access financing in the mainstream commercial banks. This is partially attributed to the stringent measures taken by commercial banks to shield themselves from non-performing loans. The provision and delivery of financial services and credit to the sector by formal financial institutions has been below expectation. This is because only less than $10 \%$ of MSEs receive credit and other financial services from formal banking sector implying that over $90 \%$ receive credit facilities from the informal sector (ROK, 2016). Some of the criteria used by commercial banks in assessing borrowers are savings level, steady cash flow, and availability of assets to use as collateral as well as economic factors such as interest rates and central bank base rate. In addition, commercial banks assess the risk profile of the borrower (Essendi, 2013). Due to the stringent measures, many investment groups find it difficult to borrow from commercial banks. For this reason, they turn to microfinance institutions such as the Sidian Bank for credit facilities.

Several studies have been carried out attempting to explain the determinants of portfolio quality. In the international scene, Knaup and Wagner (2012) developed a market-based measure of credit portfolio quality and banks' performance during the subprime crisis. Love and Ariss (2014) 
conducted a panel analysis of economic shocks and loan portfolio quality in Egypt. Kar and Swain (2014) sought to determine if microfinance competition affect performance, portfolio quality, and its capitalization. Makri, Tsagkanos and Bellas (2014) established the determinants of non-performing loans in Eurozone while Bougatef and Bougatef (2016) evaluated how corruption affects loan portfolio quality in emerging markets.

None of these reviewed studies established the effect institutional micro-credit determinants have on portfolio quality of investment. This study therefore sought to fill this gap by answering the question; what is the effect institutional micro credit determinant on portfolio quality of investment groups financed by the Sidian bank in Nairobi region?

\section{Objectives of the study}

The objective of the study was to establish the institutional effect micro credit determinants on portfolio quality of investment groups financed by the Sidian bank in the Nairobi region.

\section{Research Hypothesis}

There is no effect of institutional micro credit determinant on portfolio quality of investment groups financed by the Sidian bank in the Nairobi region.

\section{Literature Review}

This study seeks to establish the relationship that exists between institutional micro credit determinants and portfolio quality of investment groups financed by the Sidian bank in Nairobi region. The study therefore attenuated the nature of the key constructs in the conceptualization emanating from micro credit determinants to create a phenomenon leading to portfolio quality. The study thus calls for an examination of relevant theories that can explain this phenomenon. The study considers the postulates and contributions of the modern portfolio theory, information asymmetry theory, the agency theory and the efficient frontier model.

\section{The Modern Portfolio Theory}

Modern Portfolio Theory (MPT) is attributed to Harry Markowitz, which was published in his paper 'Portfolio Selection' in the Journal of Finance, 1952. The theory proposes a hypothesis on the basis of which, expected return on a portfolio for a given amount of portfolio risk is maximized or the risk on a given level of expected return is minimized. According to Pfaff (2012), the theory shows how rational investors diversify in order to optimize their portfolios. Francis and Kim (2013) noted that this can be by choosing quantities of various securities cautiously taking into consideration the way in which the prices of each security changes in 
comparison to that of every other security in the portfolio, rather than choosing securities individually. The portfolio theory uses mathematical models to construct an ideal portfolio for an investor that gives maximum return depending on his risk appetite by taking into consideration the relationship between risk and return (Mangram, 2013). According to the theory as noted by Pfaff (2012), each security has its own risks, which is higher than that of a portfolio containing diverse securities. Simply put, the theory emphasizes on the importance of diversification to reduce risk.

Financial portfolios use Modern Portfolio Theory (MPT), which deals with problems of risk and return, to make investment allocation decisions. According to Swamy(2013), the bearing of MPT on business decision-making among microfinance institutions has been substantial such that the quality of portfolio is now routinely assessed for risk as well as return through the MPT for optimal decision making. The Modern Portfolio Theory links the expected rate of return of portfolio to the expected risk showing the importance of diversification in the minimization of portfolio risk hence its importance for consideration as it provides a mathematical linkage between the concept ofinstitutional micro credit determinants and portfolio quality (Chen, 2016).

\section{Information Asymmetry Theory}

Information asymmetry (Armstrong, Core, Taylor and Verrecchia, 2011) refers to a situation where one party has more or better information than the other. Asymmetric information (Suri and Adnan, 2016) is more prevalent in financial markets such as borrowing and lending where the borrower has much better information about his financial state than the lender. This creates an imbalance of power in transactions, which can sometimes cause the transactions to go awry, or market failure in the worst case.Akerlof (1970) first presented this theory.

The Finance theory postulates that information asymmetry can constrain all types of external financing by either limiting availability or increasing costs. Consequently, information asymmetry should affect the acquisition and use of microfinance bank loans since microcredit loan is a primary source of firm liquidity. Moreover, if monitoring is imperfect and the lenders cannot eliminate information asymmetry, bank credit may be rationed for opaque firms. On an indirect basis, information asymmetry may also influence line of credit availability and use since some sources of repayment are based on access to public capital markets (Hill, Kelly \& Hardin, 2010).

\section{The Agency Theory}

Agency theory was first conceived by Ross (1973) and Mitnick (1973), who independently developed economic theory of agency and the institutional theory of agency respectively. An agency relationship arises where one party 
known as the principal gives legal authority to another party known as the agent to act on the principal's behalf in dealing with third parties. The theory suggests a divergence in interests between the principle and the agent develops into an agency conflict. In a firm, the dominant agency relationship is between the owners of the firm and the management. This theory therefore seeks to explain the relationship that exists between the management of the organization and the shareholders (Miller \& Sardais, 2011).

The theory also posits that owners can constrain management's ability to maximize personal utility by establishing contracts that minimizes the divergence in interests in exchange for a level of salary and benefits to management that is greater than what owner-managers would grant them if they were in control of the firm (Shi, Connelly \& Hoskisson, 2016).

Erhard and Jensen (2014) posit that a firm should consider the agency costs of debt vis a vis the benefits of debt to determine the optimum debt. Optimum debt according to them is the point at which marginal agency costs of debt is equal to marginal benefits of debt. They identified the agency costs of debt as consisting of the agency theory of capital structure. Consistent with agency theory postulates, microfinance institutions with higher leverage or lower equity are associated with lower portfolio quality. In terms of bank size, smaller banks are more efficient whereas medium size and larger banks are cost efficient (Ndungu \& Njeru, 2014).

\section{The Financial Intermediation Theory}

Financial intermediation involves surplus units depositing funds with financial institutions who then lend to deficit units. In earlier studies of financial intermediation, such as Gurley and Shaw's (1960), the main activity of intermediaries was the transformation of securities issued by firms (shares and bonds) into securities demanded by investors (deposits). Financial intermediaries are valuable because they provide services of divisibility and risk transformation, which borrowers cannot obtain on their own under identical conditions due to transaction costs.

\section{Macroeconomic Variables}

Microcredit can create considerable opportunities for people to utilize lumps of money so that they can improve incomes and reduce vulnerability. But not all micro credit produces favourable results, especially for poor people working in low-return activities in saturated markets that are poorly developed and where environmental and economic shocks are common (Kantor, 2009). Portfolio quality of financial institutions may also be influenced by several factors, which are beyond the control of the firm. External factors influencing portfolio quality may include interest rate, inflation rate, exchange rate and economic growth. 


\section{Interest Rate}

From both theoretical and empirical perspective, interest rates affect economic growth, which in turn affects total taxes, collected in a country as observer by Udoka and Anyingang (2015). Additionally, Ng'etich and Wangari (2011) observed that high interest rates have the negative effect of increasing the cost of borrowing and consequently limiting the level of aggregate investment and consumption and the overall portfolio quality in an institution. Interest rate levels are influenced by markets forces, supply and demand factors, inflation and default risk (Jiang, Nelson \& Vytlacil, 2014). Government's policy also plays an important role. While national approaches to interest rate management differ from one country to another and over time, no country permits its interest rates to be determined solely by market forces. Even when interest rates are not actually determined by government, it is common for government agencies to act as market participants in attempts to achieve desired levels.

\section{Inflation Rate}

Literature supports that there is a direct relationship between inflation rate and loan portfolio quality such that if the rate of inflation will increase total loan defaults will increase (Lucotte, 2010). Rasheed and Jabeen (2016) observed that inflation ties up money that could be used to pay for loans by individuals and firms. Inflation disturbs the distribution of income and wealth by creating unemployment and lowering economic growth making it difficult for borrowers to arrange for loan repayment. It creates uncertainty and raises costs of production. Profitability of investment is lowered making it less attractive as a result. This will in turn lowers tax collection since the government will lose the revenue that would have been generated if the investment were profitable. Inflation hurts people on fixed incomes, since their purchasing power will fall.

Ngotho and Kerongo (2014) reported that when inflation rises there is a negative effect on revenue collection. In their observation, they indicated that when inflation falls, revenue collection increases. When inflation rises it affects the cost of living and that of doing business leading to tax evasion. Finally, they support the view that inflation will affect growth through reducing the efficiency of resources' allocation. He develops a model to elaborate that inflation will change return on money and capital and then alter the choice by firms and consumers.

\section{Exchange Rate}

Economists have long known that poorly managed exchange rates can be disastrous for economic growth (Easterly, 2005). A high real exchange rate (undervaluation of the currency) stimulates economic growth. This is true 
particularly for the developing countries of which Kenya is among them. Exchange rates play a vital role in a country's level of trade. A higher exchange rate can be expected to lower the country's balance of trade while a lower exchange rate would increase it. As affirmed by Clark and Ghosh (2004), foreign exchange affects international trade and capital flows.

\section{Unemployment rate}

Unemployment rate is simply defined as the percentage of entire labour force that is unemployed but keenly looking for a job and willing to contribute (Bernstein, 2014). As unemployment rate increases, many people may want to give a try on starting their own business. However, not all loans given out guarantee a $100 \%$ payback, especially during economic recessions. Punyaratabandhu (1999) added that a country might face worse situation if the unemployment rate continues to escalate, eventually NPL multiplies and zero economic intensification. For instance, Japan, in the year 2000, faced the worst economy ever. Their NPL amount was unimaginable and partly was due to the unemployment rate (Kroft \& Notowidigdo, 2016).

\section{Group Leverage Level}

To manage their portfolios, bankers and other microfinance institutions must understand not only the risk posed by each credit but also how the risks of individual loans and portfolios are interrelated. These interrelationships can multiply risk beyond what it would be if the risks were not related. Until recently, few banks used modern portfolio management concepts to control credit risk. Now, many banks view the loan portfolio in its segments and as a whole and consider the relationships among portfolio segments as well as among loans. These practices provide management with a more complete picture of the bank's credit risk profile and with more tools to analyse and control the risk (Aaker, 2009). Ward and Price (2006) defined financial leverage as the proportion of capital which is financed by debt as opposed to equity. Therefore, the higher the leverage, the higher the amount of debt in the capital structure of a firm. Financial leverage comes in various forms and has different maturity and priority structures. When a firm decides to borrows, it must decide not only on the amount but also on the type of debt finance, on the maturity and on the priority of the debt (Saunders \& Cornett, 2014). Companies have to decide on whether debt should be in the form of leases, convertible loans, loan capital, bank loans and overdraft, notes and bills; should be short or long-term and whether debt should be secured, unsecured or subordinated. 


\section{Group Capitalization}

Capitalization of financial institutions may be viewed in two perspectives to either refer to the book value of capital, which is the sum total of the company's debt and equity. On the other hand, capitalization may be viewed as the market value of capital and which depends on the price of the company's stock (Malkiel, 2014). It is determined by multiplying the price of the company's shares by the number of shares outstanding in the market.

As noted earlier, market capitalization is the market value of capital (Malkiel, 2014) and basically depends on the price of the company's stock in an open market. An investment group may be overcapitalized, undercapitalized or medium capitalized. Overcapitalization refers to a situation where earnings are not enough to cover the cost of capital such as interest, or dividends payments to shareholders. Companied which have just adequate capitalizations are referred to as mid-caps. Interest on debt is a deductible expense for tax purposes. This provides investment groups with an incentive to finance their operations with debt rather than equity, especially in high tax countries (Gallagher, Gardner, Schmidt \& Walter, 2014).

\section{Group Characteristics}

Research has attempted to explain loan repayment behaviour by individual factors related to the borrower characteristics, whereas some others explain the payment by the institutional determinants. That is factors related to institutional characteristics of MFI. Other categories of factors can explain PAR such as nature of contract, nature of activity, social ties between group members and cultural factors. Giné and Karlan (2014) focused on the effects of program design, community and group characteristics on the repayment performance of groups. The results show that socially cohesive groups pool risks by diversifying the members' asset portfolio so that their repayment performance is improved even in communities with high-risk exposure. Same group characteristics include savings level, Group size, Nature of activity and Level of income among others.

\section{Savings level}

Microfinance institutions lending to investment groups rely on the level of savings by the group as a whole as well as individual member savings.Giné and Karlan (2014) notes that mandatory and voluntary savings schemes have been used effectively where savings play a significant role in gaining access to credit. Resnik (2010) identifies savings as a means of determining who to give credit and how much, whereby a borrower is required to accumulate savings both prior to and after borrowing. 


\section{Group size}

Group size has a major influence in determination of the level of credit available to the group. This is due to the fact that large groups may have more assets and thus can access external finance cheaply due to their asset base and thus the ability to influence the rate of interest to their advantage. Large firms can also survive during crisis than small firms due to accumulated reserves (Ooghe \& Prijcker, 2008). Armstrong, et. al.(2011) concluded that delay in reimbursement may result from certain characteristics related to the borrower: age, gender, educational level and matrimonial status. Other features are related to the requested loan: the amount requested the number of repayments, the number of loans, and the difference of the loan amount with the previous, the method of individual granting and the type of credit. Finally, the experience of the credit agent plays a key role in detecting doubtful customers.

\section{Nature of activity}

Profit oriented MFIs may be motivated to enter markets where the penetration of the existing socially motivated MFIs is high (McIntosh and Wydick, 2005). Profit maximizing MFIs select their clients from the alreadytrained and screened set of clients of the socially motivated MFIs, which adversely influences socially motivated MFIs' outreach performance. Loan repayment problems coupled with increased competition and information asymmetry may also lead to a decline in portfolio quality (Buttell, 2010) and expose the MFI clients to the risk of over-indebtedness and debt-traps leading to increased sociological and psychological constraints (Bhattacharya, et. al., 2013).The environment in which the institution is operating has also been ranked as a major factor determining the accessibility to microcredit. Institutional condition here refers to the overall environment including commercial, socioeconomic, technological and political environment, which directly influence the nature of activity for the group.

\section{Level of income}

Maurer (2014) observed that causes of default especially in the agricultural sector are mainly inadequate income, crop failure, high instalment of repayment, lack of understanding of terms, liquidity problem, excessive debt taking, Ineffective storage/marketing, improper selection of borrowers, political pressure and interference, lack of co-operation from the government, lack of proper Supervision. Al Azzam \& Mimouni (2012) suggested that social ties that are founded on friendship, neighbourhood, and on good communication seem to lower the number of days of late repayment. Therefore, social ties between group members improve group repayment performance. 
A client's capacity can be determined by retrieving his resources of income and netting off the commitments. In the case of a company, an analysis of the Audited Accounts for the past three years could reveal the surplus available to service the loan. Occasionally, credit managers come across clients who will tell them that they are good borrowers because this is their first loan. Unfortunately, one cannot say so because these clients are inexperienced. They are virgins in loan management and repayment (Poghosyan, 2013).

\section{Portfolio Quality}

Non-Performing Loans (NPLs) are also called Non-Performing Assets (NPAs). A Nonperforming Loan/ Asset are a credit facility in respect of which the interest and or principal amount has remained past due for a specific period of time. Many financial institutions attempting to manage their portfolio quality are concerned with credit risk. Credit risk mitigation is the application of different strategies by lenders, banks and other business offering credit to control loss from default and promote credit demand. As discussed by Bandyopadhyay (2007) the practice includes risk-based pricing, cost adjustment to the credit strength of the borrower; credit tightening and information management through technical assistance. Other techniques to minimize credit risk include; advisory services and literacy, diversification or increasing portfolio- mix of borrowers as well as purchasing credit insurance. Portfolio at Risk $(\mathrm{PaR})$ is calculated by dividing the outstanding balance of all loans with arrears over 30 days, by the outstanding gross portfolio as of a certain date. 


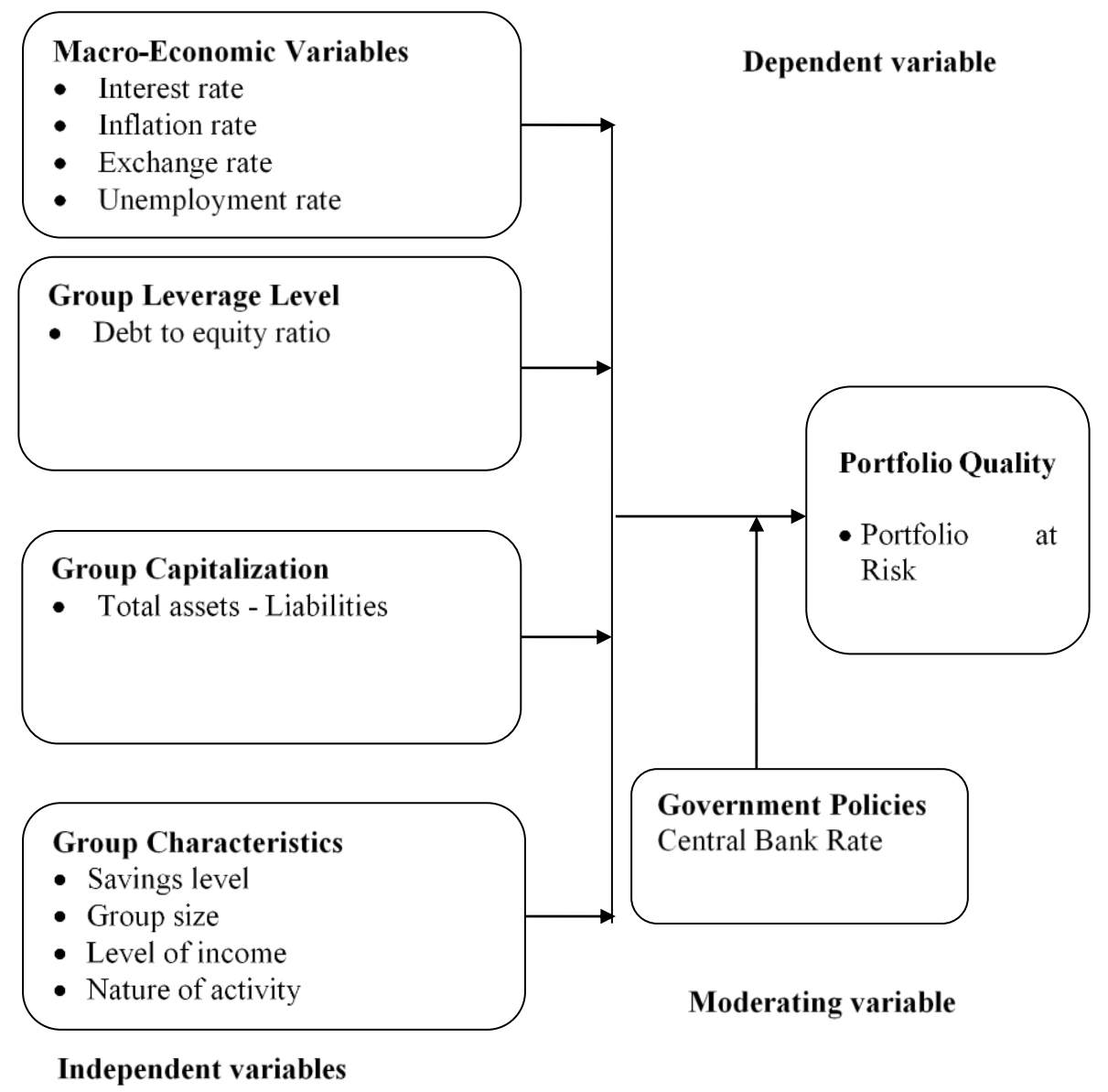

Figure 1: Conceptual Framework

\section{Research methodology}

The study adopted a descriptive survey research design. This design was adopted because it describes the state of affairs, as it exists at present in the study (Taylor, Bogdan \& DeVault, 2015). The researcher intends to apply this design to evaluate the relationship between institutional micro credit determinants and portfolio quality of investment groups under the Sidian bank. This study was based in Nairobi County and the target population was all the 56 investment groups in the 9 branches under the Sidian bank within the Nairobi region (Sidian bank, 2017). The study targeted the group officials and their Managers in this region.

This study used secondary data, which was obtained from the Sidian bank offices in each of the branches within Nairobi region. Secondary data was used because data relating to investment groups financed by the Sidian bank is readily available from the credit manager and other credit officers in 
the Sidian bank offices as well as their website (https://www.sidianbank.co.ke).

Data relating to macroeconomic variables can also be easily obtained from central bank website (https://www.centralbank.go.ke) as well as Kenya bureau of statistics (KNBS) website, https://www.knbs.or.ke. Data obtained was entered into Statistical Packages for Social Sciences (SPSS V 21) for analysis.

Correlation analysis was used to establish the relationship that exists between the independent variable and the dependent variable. Regression analysis was conducted to show how macroeconomic variables, group leverage level, group capitalization and group characteristics influence portfolio quality of investment groups financed by the Sidian bank in Kenya. Portfolio quality was measured using portfolio at risk.

The regression model was as follows:

$Y=b_{0}+b_{1} x_{1}+b_{2} x_{2}+b_{3} x_{3}+b_{4} x_{4}+\varepsilon$

Where: $\boldsymbol{Y}=$ Portfolio quality as measured by Portfolio at Risk.

Portfolio at Risk $=$ (Outstanding Balance on Arrears over 30 days /

Total Outstanding Gross Portfolio (Total loan)

$\boldsymbol{x}_{\boldsymbol{1}}=$ Macroeconomic variables as measured by interest rate, inflation rate, exchange rates and unemployment rate

$\boldsymbol{x}_{2}=$ Group leverage level measured by Debt to equity ratio $=$ Total liabilities/ Total equity

$\boldsymbol{x}_{3}=$ Group capitalization measured $=$ Total assets- Total liabilities

$\boldsymbol{x}_{\mathbf{4}}=$ Group characteristics measured by Savings level, Group size and Level of income.

$\varepsilon=$ Error term

$\mathrm{b}_{0}=$ Constant Term;

$\mathrm{b}_{1}, \mathrm{~b}_{2}, \mathrm{~b}_{3}$ and $\mathrm{b}_{4}=$ Beta coefficients;

\section{Results and Discussion}

\section{Descriptive Statistics}

This section focuses on the general description of the study variables characteristics including the, mean, standard deviation, skewness and kurtosis for portfolio at risk, group leverage level, group capitalization measured and group characteristics. 


\section{Portfolio at Risk}

The findings for Portfolio at Risk are as presented in Table 1.

Table 1: Descriptive Statistics for Portfolio at Risk

\begin{tabular}{lcccccc}
\hline Year & 2012 & 2013 & 2014 & 2015 & 2016 & Aggregate \\
\hline $\begin{array}{l}\text { Annual Average (Mean) for } \\
\text { Portfolio at Risk }\end{array}$ & 0.379 & 0.262 & 0.303 & 0.248 & 0.264 & 0.291 \\
Std. Dev. & 0.021 & 0.0058 & 0.053 & 0.081 & 0.055 & 0.043 \\
Skewness & 1.445 & 1.037 & 1.180 & 1.078 & 0.549 & 1.058 \\
Kurtosis & 0.053 & 0.041 & 0.237 & 0.113 & 0.119 & 0.113 \\
\hline
\end{tabular}

Source; Survey Data (2019)

The results in Table 1 showed that portfolio at risk had a mean score of 0.291. Analysis of skewness shows that portfolio at risk is asymmetrical to the left around their mean. The kurtosis for portfolio at risk was greater than zero hence their data exhibits leptokurtic distribution (Chang, 1999). The problem of non-performing loans can put serious adverse effects on the economy; the government has implemented various policy measures for management of non-performing loans and securing confidence in the financial system. Quality of assets in lending technologies is normally measured by the quantum of non-performing loans and has been found a direct and interlinked relationship between both.

\section{Group Leverage Level}

The findings for Group leverage level were as illustrated in Table 2.

Table 2: Descriptive Statistics for Group leverage level

\begin{tabular}{lcccccc}
\hline Year & 2012 & 2013 & 2014 & 2015 & 2016 & Aggregate \\
\hline $\begin{array}{l}\text { Annual Average (Mean) for } \\
\text { Group leverage level }\end{array}$ & & 0.323 & 0.446 & 0.813 & 0.315 & 0.545 \\
Std. Dev. & 0.325 & 0.266 & 0.474 & 0.118 & 0.224 & 0.28 \\
Skewness & 0.462 & 0.737 & 0.340 & 0.538 & 0.521 & 0.527 \\
Kurtosis & 0.521 & 0.412 & 0.621 & 1.013 & 1.203 & 0.752 \\
\hline
\end{tabular}

Source; Survey Data (2019)

The results in Table 2 showed that group leverage level had a mean score of 0.545. Analysis of skewness shows that group leverage level is asymmetrical to the left around their mean. The kurtosis for group leverage level was greater than zero hence their data exhibits leptokurtic distribution. The findings are also consistent with these findings agree with Saunders and Cornett (2014) who argued that the higher the leverage, the higher the amount of debt in the capital structure of a firm. Financial leverage comes in various forms and has different maturity and priority structures. When a firm decides to borrows, it must decide not only on the amount but also on the type of debt finance, on the maturity and on the priority of the debt. 


\section{Group Capitalization}

The findings for group capitalization are as shown in Table 3.

Table 3: Descriptive Statistics for Group capitalization

\begin{tabular}{lcccccc}
\hline Year & 2012 & 2013 & 2014 & 2015 & 2016 & Aggregate \\
\hline $\begin{array}{l}\text { Annual Average (Mean) } \\
\text { for Group Capitalization }\end{array}$ & 7.65 & 7.744 & 7.912 & 8.005 & 8.208 & 6.696 \\
Std. Dev. & & & & & & \\
Skewness & 0.368 & 0.684 & 0.598 & 0.228 & 0.844 & 0.545 \\
Kurtosis & -0.591 & -0.811 & -0.766 & -0.966 & -0.781 & -0.784 \\
\hline
\end{tabular}

\section{Source; Survey Data (2019)}

The results in Table 3 showed that group capitalization measured had a mean score of 6.696 Analysis of skewness shows that group capitalization measured is asymmetrical to the left around their mean. The kurtosis for group capitalization measured is less than zero hence their data depicts platykurtic distribution. This is consistent with Malkiel (2014) who argues that market value of capital and basically depends on the price of the company's stock in an open market. An investment group may be overcapitalized, undercapitalized or medium capitalized. Overcapitalization refers to a situation where earnings are not enough to cover the cost of capital such as interest, or dividends payments to shareholders. Companied which have just adequate capitalization is referred to as mid-caps. Interest on debt is a deductible expense for tax purposes.

\section{Group Characteristics}

The findings for Group characteristics were as illustrated in Table 4.

Table 4: Descriptive Statistics for Group characteristics

\begin{tabular}{lcccccc}
\hline Year & 2012 & 2013 & 2014 & 2015 & 2016 & Aggregate \\
\hline $\begin{array}{l}\text { Annual Average (Mean) } \\
\text { for Group Characteristics. }\end{array}$ & 7.492 & 7.631 & 7.747 & 7.877 & 7.927 & 6.603 \\
Std. Dev. & 0.351 & 0.431 & 0.383 & 0.241 & 0.105 & 0.303 \\
Skewness & -0.133 & 0.232 & -0.015 & -0.314 & -0.364 & -0.118 \\
Kurtosis & -1.978 & -0.879 & 0.062 & 0.124 & -1.965 & -0.927 \\
\hline
\end{tabular}

Source; Survey Data (2019)

The results in Table 4 showed that Group characteristics had a mean of 6.603. Analysis of skewness shows that group characteristics are asymmetrical to the left around their mean. The kurtosis for group characteristics is less than zero hence their data depicts platykurtic distribution. These findings agree with Resnik (2010) who identifies savings as a means of determining who to give credit and how much, whereby a borrower is required to accumulate savings both prior to and after borrowing. The borrower may also be required to pledge such savings as collateral. 


\section{Macroeconomic Variables}

The findings for those macroeconomic variables were as illustrated in Table .5 .

Table 5: Descriptive Statistic for Macroeconomic Variables

\begin{tabular}{lcccc}
\hline & Mean & Std. Dev. & Skewness & Kurtosis \\
\hline Interest rate & 13.8 & 0.865 & 0.869 & -0.141 \\
Inflation rate & 6.976 & 2.871 & 2.267 & 6.090 \\
Exchange rates & 91.65 & 7.662 & 0.033 & -0.008 \\
Unemployment Rates & 11.68 & 0.1584 & -0.006 & -0.716 \\
\hline
\end{tabular}

Source: Survey Data (2019)

The findings in Table 5 showed that interest rate had a mean score of 13.8 , inflation rate had a mean score of 6.976 , and exchange rates had a mean score of 91.65 while unemployment rate averaged 11.68. Analysis of skewness shows that interest rate, inflation rate, exchange rates and unemployment rate were asymmetrical to the right around their mean. The kurtosis for interest rate and exchange rates and Unemployment Rates were less than zero hence their data exhibits platykurtic distribution while for inflation rate was greater than zero hence their data depicts leptokurtic distribution. This is in agreement with Ng'etich and Wangari (2011) who observed that high interest rates have the negative effect of increasing the cost of borrowing and consequently limiting the level of aggregate investment and consumption and the overall portfolio quality in an institution. Interest rate levels are influenced by markets forces, supply and demand factors, inflation and default risk. The descriptive statistics obtained are summarized as follows:

\section{Inferential Statistics}

The study conducted both regression analysis and correlation for this study. Correlation analysis was used to establish the relationship that exists between the independent variable and the dependent variable. Regression analysis was conducted to show how macroeconomic variables, group leverage level, group capitalization and group characteristics influence portfolio quality of investment groups financed by the Sidian bank in Kenya.

\section{Correlation Analysis}

Pearson's correlations analysis was then conducted at $95 \%$ confidence interval and 5\% confidence level 2-tailed. 


\begin{tabular}{|c|c|c|c|c|c|c|}
\hline & & 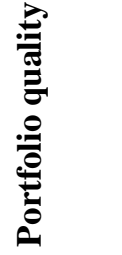 & 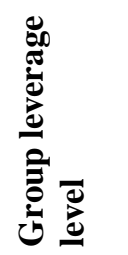 & 을 & & - \\
\hline Portfolio quality & $\begin{array}{l}\text { Pearson Correlation } \\
\text { Sig. (2-tailed) }\end{array}$ & 1 & & & & \\
\hline $\begin{array}{l}\text { Macroeconomic } \\
\text { variables }\end{array}$ & $\begin{array}{l}\text { Pearson Correlation } \\
\text { Sig. (2-tailed) }\end{array}$ & $\begin{array}{l}.847^{*} \\
.047\end{array}$ & & & & \\
\hline Group leverage & Pearson Correlation & $.858^{*}$ & 1 & & & \\
\hline level & Sig. (2-tailed) & .000 & & & & \\
\hline Group & Pearson Correlation & $.764^{*}$ & $.666^{*}$ & 1 & & \\
\hline capitalization & Sig. (2-tailed) & .002 & .000 & & & \\
\hline Group & Pearson Correlation & $.740^{*}$ & $.252^{*}$ & $.272^{*}$ & 1 & \\
\hline characteristics & Sig. (2-tailed) & .009 & .003 & .038 & & \\
\hline
\end{tabular}

The findings show that macroeconomic variables and portfolio quality of investment groups financed by the Sidian bank in Kenya are positively correlated as shown by 0.847 . Further, as shown by a coefficient of 0.858 , Group leverage level and portfolio quality of investment groups financed by the Sidian bank in Kenya are positively correlated. Moreover, the study found that group capitalization and portfolio quality of investment groups financed by the Sidian bank in Kenya are strongly and positively related as shown by 0.764 . Further the study found that group characteristics and portfolio quality of investment groups financed by the Sidian bank in Kenya are positively correlated as shown by 0.740 . Finally, it was established that government policies were positively correlated with portfolio quality, macroeconomic variables, group leverage level, group capitalization and group characteristics as shown by correlation coefficients of $0.047,0.320,0.015$ and 0.151 respectively. It was further established that these coefficients were significant at 95\%confidence level. This concurs with Nduba (2010) who notes that customer characteristics include, character, capacity, condition, collateral contribution and finally, common sense. Character refers to maturity, honesty and trustworthiness, integrity, discipline, reliability and dependability of a customer. Character is no doubt the most important quality of any client. A person of good character will pay his debt whether it is secured or not. Such a person will disclose all the facts of his deal because his intentions are to seek guidance and help from the organization. 


\section{Multiple Regression Analysis}

In this study, a multiple regression analysis was conducted to test the influence among predictor variables. The regression model ; $Y=b_{0}+b_{1} x_{1}+b_{2} x_{2}+b_{3} x_{3}+b_{4} x_{4}+\varepsilon$

The model summary is presented in the Table 7.

Table 7: Model Summary

\begin{tabular}{ccccc}
\hline Model & $\mathrm{R}$ & R Square & Adjusted R Square & Std. Error of the Estimate \\
\hline 1 & 0.837 & 0.701 & 0.678 & 2.113 \\
\hline
\end{tabular}

The study used coefficient of determination to evaluate the model fit. The adjusted $\mathrm{R}^{2}$, also called the coefficient of multiple determinations, is the percent of the variance in the dependent explained uniquely or jointly by the independent variables. The model had an average coefficient of determination $\left(\mathrm{R}^{2}\right)$ of 0.837 and which implied that $83.7 \%$ of the variations in portfolio quality of investment groups financed by the Sidian bank in Kenya are explained by changes in macroeconomic variables, group leverage level, group capitalization and group characteristics. The analysis of variance results were as shown in Table 8.

Table 8: Analysis of Variance (ANOVA)

\begin{tabular}{ccccccc}
\hline & Model & Sum of Squares & Df & Mean Square & F & Sign. \\
\hline \multirow{2}{*}{1} & Regression & 566.126 & 4 & 141.532 & 29.930 & .000 \\
\cline { 2 - 7 } & Residual & 241.168 & 51 & 4.729 & & \\
\cline { 2 - 7 } & Total & $\mathbf{8 0 7 . 2 9 4}$ & $\mathbf{5 5}$ & & & \\
\hline
\end{tabular}

From the ANOVA, the study established the regression model had a significance level of $0.00 \%$ which is an indication that the data was ideal for making a conclusion on the population parameters as the value of significance (p-value) was less than 5\%. The calculated $\mathrm{F}$ value was greater than the $\mathrm{F}$ critical value $(29.930>2.4088)$. The significance value was less than 0.05 indicating that the model was significant. Therefore the null hypothesis was rejected implying that institutional micro credit determinant have effect on portfolio quality of investment groups financed by the Sidian bank in the Nairobi region.

This concurs with Roslan and Karim (2009) who found that repayment performance is significantly affected by borrower's characteristics, lenders characteristics and loan characteristics. Repayment problems can be in form of loan delinquency and default. 
Table 9: Regression Coefficients

\begin{tabular}{lccccc}
\hline & \multicolumn{2}{c}{ Un standardized } & Standardized & t & Sig \\
\cline { 2 - 5 } & Coefficients & Coefficients & & \\
\cline { 2 - 5 } & $\mathbf{B}$ & $\begin{array}{c}\text { Std. } \\
\text { Error }\end{array}$ & Beta & & \\
\hline (Constant) & 0.988 & 0.112 & & 8.821 & .000 \\
Macroeconomic variables & 0.856 & 0.393 & 0.733 & 2.178 & .034 \\
Group leverage level & 0.896 & 0.345 & 0.761 & 2.597 & .012 \\
Group capitalization level & 0.767 & 0.239 & 0.718 & 3.209 & .002 \\
Group characteristics & 0.742 & 0.298 & 0.702 & 2.490 & .016 \\
& & & & & \\
\hline
\end{tabular}

The regression equation obtained from this outcome was: -

As per the study results, it was revealed that if all independent variables were held constant at zero, then the portfolio quality of investment groups financed by the Sidian bank in Kenya will be 0.988 . From the findings the study revealed that if macroeconomic variables increase by one unit, then portfolio quality of investment groups financed by the Sidian bank in Kenya would increase by 0.856 . This variable was significant since $p=0.034$ is less than 0.05. This is in line with Rasheed and Jabeen (2016) observed that inflation ties up money that could be used to pay for loans by individuals and firms. Inflation disturbs the distribution of income and wealth by creating unemployment and lowering economic growth making it difficult for borrowers to arrange for loan repayment. It creates uncertainty and raises costs of production. Kyule and Ngugi (2014) concluded that interest rates are influenced by inflationary conditions, open market factors including foreign interest rates and the expected depreciation of local currency, monetary conditions and output levels.

The study further revealed that if Group leverage level changes it would lead to 0.896 changes in portfolio quality of investment groups financed by the Sidian bank in Kenya. The variable was significant since pvalue $=0.012<0.05$. Moreover, the study showed that if all other variables are held constant, variation in group capitalization level variates portfolio quality of investment groups financed by the Sidian bank in Kenya by 0.767 . This variable was significant since $\mathrm{p}=0.002$ was less than 0.05 . Finally, the study revealed that variation in group characteristics would change the portfolio quality of investment groups financed by the Sidian bank in Kenya by 0.742 . This variable was significant since $p$-value $=0.016$ was less than 0.05 . This corresponds to Saunders and Cornett (2014) who opined that companies have to decide on whether debt should be in the form of leases, convertible loans, loan capital, bank loans and overdraft, notes and bills; should be short or longterm and whether debt should be secured, unsecured or subordinated.

Generally, group leverage level had the greatest influence on portfolio quality of investment groups financed by the Sidian bank in Kenya followed 
by macroeconomic variables while group capitalization level then group characteristics had the least effect on the portfolio quality of investment groups financed by the Sidian bank in Kenya. All the variables were significant since p-values were less than 0.05. This conforms to Aaker (2009) findings that to manage their portfolios, bankers and other microfinance institutions must understand not only the risk posed by each credit but also how the risks of individual loans and portfolios are interrelated.

\section{Conclusion}

The study concluded that macroeconomic variables significantly influence portfolio quality of investment groups financed bythe Sidian bank in Kenya. Kyule and Ngugi (2014) concluded that interest rates are influenced by inflationary conditions, open market factors including foreign interest rates and the expected depreciation of local currency, monetary conditions and output levels.

The study further concluded group leverage level significantly influences portfolio quality of investment groups financed by the Sidian bank in Kenya. This was in agreement with Caprio (2006) who opined that a weak legal system, where the courts are not oriented toward prompt enforcement of contracts and property rights are ill defined, increases credit riskiness and MFIs have no incentive to charge lower rates.

The study concluded that group capitalization level influence variations in portfolio quality of investment groups financed by the Sidian bank. This agrees with Beck, Jakubik and Piloiu (2013) who argues that companies can be ranked according to their market capitalizations, and the general format is to rank them as large-cap, mid-cap and small-cap companies.

The study concluded that variation in group characteristics influences the portfolio quality of investment groups financed by the Sidian bank in Kenya. This is in line with Giné and Karlan (2014) who focused on the effects of program design, community and group characteristics on the repayment performance of groups.

The study concluded that government policies have a significant moderating effect on the relationship between institutional micro credit determinants and portfolio quality of investment groups financed by the Sidian bank in Nairobi region.

\section{Recommendations}

The study recommends that the Sidian bank need to manage their portfolios, by understanding that not only the risk posed by each credit but also how the risks of individual loans and portfolios are interrelated. The study also recommended that, banks should be allowed to invest more in loans and advances as long as such banks have enough reserves to finance such 
investments and that banks should be allowed to scale up their operations so long as there is adequate capitalization to support their growth. The study further recommends that regulatory authority $(\mathrm{CBK})$ and other stake holders should create an enabling environment that removes all these inefficiencies to the policy concern of high cost of credit.

\section{References:}

1. Aaker, D. A. (2009). Brand portfolio strategy: Creating relevance, differentiation, energy, leverage, and clarity. Simon and Schuster.

2. Akerlof, G. A. (1970). The market for" lemons": Quality uncertainty and the market mechanism. The quarterly journal of economics, 488500 .

3. Armstrong, C. S., Core, J. E., Taylor, D. J., \& Verrecchia, R. E. (2011). When does information asymmetry affect the cost of capital?Journal of Accounting Research, 49(1), 1-40.

4. Bandyopadhyay, A. (2007). Credit risk models for managing bank's agricultural loan portfolio. Journal of Banking \& Finance, 33(2), 281299.

5. Bernstein, A. (2014). South Africa's key challenges: Tough choices and new directions. The annals of the American Academy of Political and Social Science, 652(1), 20-47.

6. Bhattacharya, N., Desai, H., \& Venkataraman, K. (2013). Does earnings quality affect information asymmetry? Evidence from trading costs. Contemporary Accounting Research, 30(2), 482-516.

7. Buttell, A. E. (2010). Harry M. Markowitz on modern portfolio theory, the efficient frontier and his life's work. Journal of Financial Planning, 23(5), 18-23.

8. Chang, C. C. (1999). The nonparametric risk-adjusted efficiency measurement: an application to Taiwan's major rural financial intermediaries. American Journal of Agricultural Economics, 81(4), 902-913.

9. Chen, J. M. (2016). Modern Portfolio Theory. In Postmodern Portfolio Theory (pp. 5-25). Palgrave Macmillan US.

10. Chorafas, D. (2009). Financial boom and gloom: the credit and banking crisis of 2007-2009 and beyond. Springer.

11. Clark, E., \&Ghosh, D. K. (2004). Arbitrage, hedging, and speculation: the foreign exchange market. Greenwood Publishing Group.

12. Erhard, W., \& Jensen, M. C. (2014). Putting integrity into finance: A purely positive approach (No. w19986). National Bureau of Economic Research. 
13. Essendi, L. K. (2013). The effect of credit risk management on loans portfolio among Saccos in Kenya (Doctoral dissertation, University of Nairobi).

14. Francis, J. C., \& Kim, D. (2013). Modern Portfolio Theory: foundations, analysis, and new developments (Vol. 795). John Wiley \& Sons.

15. Gallagher, D. R., Gardner, P. A., Schmidt, C. H., \& Walter, T. S. (2014). Portfolio quality and mutual fund performance. International Review of Finance, 14(4), 485-521.

16. Giné, X., \& Karlan, D. S. (2014). Group versus individual liability: Short and long-term evidence from Philippine microcredit lending groups. Journal of development Economics, 107, 65-83.

17. Gurley, J. G., \& Shaw, E. S. (1960). Money in a Theory of Finance. Brookings Institution Press.

18. Hill, M. D., Kelly, G. W., \& Hardin, W. G. (2012). Market value of REIT liquidity. The Journal of Real Estate Finance and Economics, 45(2), 383-401.

19. Kar, A. K., \& Swain, R. B. (2014). Interest rates and financial performance of microfinance institutions: Recent global evidence. The European Journal of Development Research, 26(1), 87-106.

20. Knaup, M. \& Wagner, W. (2012). A market-based measure of credit portfolio quality and banks' performance during the subprime crisis. Management Science, 58(8), 1423-1437.

21. Kroft, K., \& Notowidigdo, M. J. (2016). Should unemployment insurance vary with the unemployment rate? Theory and evidence. The Review of Economic Studies, 83(3), 1092-1124.

22. Kyule, M. C., \& Ngugi, K. (2014). Influence of Capital Structure on Leverage of Small and Medium Size Enterprises in Kenya. European Journal of Business Management, 1(11), 161-181.

23. Love, I. \& Ariss, R. T. (2014). Macro-financial linkages in Egypt: A panel analysis of economic shocks and loan portfolio quality. Journal of International Financial Markets, Institutions And Money, 28, 158181 .

24. Lucotte, Y. (2010). The choice of adopting inflation targeting in emerging economies: Do domestic institutions matter? Journal of Banking \& Finance, 36(4), 1012-1027

25. Makri, V., Tsagkanos, A., \& Bellas, A. (2014). Determinants of nonperforming loans: The case of Eurozone. Panoeconomicus, 61(2), 193.

26. Malkiel, B. G. (2014). Is smart beta really smart?The Journal of Portfolio Management, 40(5), 127-134. 
27. Mangram, M. E. (2013). A simplified perspective of the Markowitz portfolio theory. The Journal of Portfolio Management, 40(5), 127134.

28. Maurer, K. (2014). Where is the risk? Is agricultural banking really more difficult than other sectors? In Finance for Food (pp. 139-165). Springer Berlin Heidelberg.

29. Milani, C. (2014). Borrower-lender distance and loan default rates: Macro evidence from the Italian local markets. Journal of Economics and Business, 71, 1-21.

30. Miller, D., \& Sardais, C. (2011). Angel agents: Agency theory reconsidered. The Academy of Management Perspectives, 25(2), 6-13.

31. Mwangi, B. W., \& Muturi, W. (2016). Effects of credit risk management on loan repayment performance of commercial banks in Kenya. International Academic Journal of Economics and Finance, 2(2), 1-24.

32. Nduba, F. M. (2010). A survey of the factors that determine credit worthiness of small and medium enterprises for bank loans (Doctoral dissertation, University of Nairobi, Kenya).

33. Ndungu, C. G., \& Njeru, A. (2014). Assessment of Factors Influencing Adoption of Agency Banking in Kenya: The Case of Kajiado North Sub County. International journal of business and commerce, 3(8), 91111.

34. Ngotho, J., \& Kerongo, F. (2014). Determinants of Revenue Collection in Developing Countries: Kenya's Tax Collection Perspective. Journal of management and business administration, 1-9.

35. Ooghe, H., \& De Prijcker, S. (2008). Failure processes and causes of company bankruptcy: a typology. Management Decision, 46(2), 223242.

36. Pfaff, B. (2012). Modern portfolio theory. Financial Risk Modelling and Portfolio Optimization with $R, 46-53$.

37. Poghosyan, T. (2013). Financial intermediation costs in low income countries: The role of regulatory, institutional, and macroeconomic factors. Economic Systems, 37(1), 92-110.

38. Rashid, A., \& Jabeen, S. (2016). Analyzing performance determinants: Conventional versus Islamic banks in Pakistan. Borsa Istanbul Review, 16(2), 92-107.

39. Resnik, B. L. (2010). Did Modern Portfolio Theory Fail Investors in the Credit Crisis?.The CPA Journal, 80(10), 10.

40. Roslan, A. H., \& Karim, M. A. (2009). Determinants of microcredit repayment in Malaysia: the case of Agrobank. Humanity \& Social Sciences Journal, 4(1), 45-52. 
41. Saunders, A., \& Cornett, M. M. (2014). Financial institutions management. McGraw-Hill Education.

42. Shi, W., Connelly, B. L., \& Hoskisson, R. E. (2016). External corporate governance and financial fraud: Cognitive evaluation theory insights on agency theory

43. Suri, A. K., \& Adnan, J. (2016). Educational Institutions and Information Asymmetry Observation in UAE. J Glob Econ, 4(213), 2.

44. Taylor, S. J., Bogdan, R., \& DeVault, M. (2015). Introduction to qualitative research methods: A guidebook and resource. John Wiley \& Sons.

45. Udoka, C. O., \& Anyingang, R. A. (2015). The Effect of Public Expenditure on the Growth and Development of Nigerian Economy (1980-2012). International Review of Management and Business Research, 4(3), 823.

46. United Nations Development Programme (UNDP) (2011). African economic outlook.

47. Ward, M., \& Price, A. (2006). Turning vision into value: corporate finance for non-financial executives. Van Schaik.

48. World Bank Group (2014). GDP per capita measured in purchasing power parity (PPP) equivalent dollars, reported as constant 2011 international dollars, based on estimates published by World Bank Group. International Comparison Program database. Washington (DC): 